\title{
Leadership Styles and Knowledge Management Strategy in Malaysian SMEs
}

\author{
Sivachandran Narayanan \\ Putra Business School, 43400 UPM Serdang, Selangor, Malaysia \\ E-mail: sivachandran.phd14@grad.putrabs.edu.my
}

Devika Nadarajah (Corresponding Author)

Putra Business School, 43400 UPM Serdang, Selangor, Malaysia

E-mail: devika@putrabs.edu.my

Sultan Adal Mehmood

Putra Business School, 43400 UPM Serdang, Selangor, Malaysia

E-mail: adilrao01@gmail.com

Nur Farhana Abdullah

Putra Business School, 43400 UPM Serdang, Selangor, Malaysia

E-mail: nurfarhana.phd16@grad.putrabs.edu.my

Received: April 9, 2020 Accepted: April 25, 2020 Published: April 28, 2020

doi:10.5296/bms.v11i1.16783 URL: https://doi.org/10.5296/bms.v11i1.16783

\begin{abstract}
This conceptual paper aims to explore the link between leadership styles and SMEs' knowledge management strategy. While previous studies have explored different leadership styles' impacts on knowledge management strategy, they have not illuminated 'why' a specific style is more effective. Therefore, this paper fills the gap in the literature by
\end{abstract}


answering two questions: (1) What leadership style is apt to promote knowledge management strategy within SMEs? and (2) Why is the particular leadership style appropriate in SMEs? This paper reviews research related transformational, transactional, servant, paternalistic, facilitative and collaborative leadership, and concludes that transformational leadership is imperative for Malaysian SMEs' knowledge management. The key implications of this paper are: (1) it sheds light on leadership and knowledge management in SMEs in particular, and (2) it posits transformational leadership as the most appropriate style for knowledge management strategy in Malaysian SMEs.

Keywords: Leadership styles, transformational leadership, knowledge management strategy, SMEs

\section{Introduction}

Knowledge management (KM) plays a significant role in economic growth in the current business world, specifically in a dynamically competitive environment involving both large corporations and small and medium enterprises (SMEs).

Knowledge is a unique resource, which distinguishes it from physical products. Managing knowledge is thus imperative for value creation in firms (Merat and Bo, 2013). The knowledge-based view perceives organizations as repositories of knowledge that are accountable for knowledge creation (Grant, 1996; Nonaka, 1994), while according to Grant and Baden-Fuller (2004), the competitive advantage of a firm is driven by its ability to exploit knowledge by integrating employees' tacit knowledge which is embedded in their minds.

Although individual employees are responsible for developing knowledge, it is the organization, through leadership, that plays a key role in disseminating and applying knowledge. Therefore, having the right leader in an organization is paramount to achieving the various elements of knowledge management. While previous studies have explored 'what' leadership styles influence KM strategy, research has failed to adequately explain 'why' a particular leadership style is crucial to KM strategy, specifically in SMEs. Thus, this conceptual paper contributes to the literature by exploring the theoretical links between six distinctive styles of leadership (transformational leadership, transactional leadership, servant leadership, paternalistic leadership, facilitative leadership, and collaborative leadership) and KM strategy in SMEs.

\section{Literature Review}

The leadership theories delineate that leaders provide a vision, mission, motivation, system, and structure at all levels of an organization. It is based on the idea that to achieve visualized goals, leaders' managerial practices must be structured well. In short, leaders must align and influence others to achieve desired objectives within formal hierarchical organizational frameworks, which includes leaders' facilitation of the conversion of knowledge into competitive advantages (Bryant, 2003). Consistent with this, the knowledge-based view 
$(\mathrm{KBV})$, derived from the resource-based view (RBV), suggests that managing knowledge is vital for firms' competitive advantages (Grant, 1996).

The theories of transformational leadership and transactional leadership have laid the foundation for the understanding of leaders' impact on the cultivation of knowledge (Bryant, 2003). However, as the world progresses from the industrial era to the knowledge era which is driven by globalization, technology, and digitalization, new challenges emerge for organizations (Barkema et al., 2002; Schneider, 2002). As such, rather than simplifying and streamlining structures, it is imperative for firms to strategize and adapt to the standards of the new age. In conjunction with this, firms, particularly SMEs, must explore and practice leadership styles that best manage and transform knowledge into competitive advantages. Notably, SME owners or leaders are significant in creating and driving knowledge management as they do so independently rather than through their employees (Wee and Chua, 2013). Thus, SMEs should nurture the most useful leadership styles for KM. The following sections discuss KM and different leadership styles.

\subsection{Small and Medium Enterprises in Malaysia}

The significant contribution of SMEs to economic development and employment is undeniably essential for almost all nations throughout the whole world.

In Malaysia, SMEs support the development of the Malaysian economy by being steering forces of the nation's progress towards industrialization (Saleh and Ndubisi, 2006). SMEs are now key drivers of growth as Malaysia heads towards becoming a developed and knowledge-based country.

Further, as per Malaysia's Tenth Plan, purported 'knowledge SMEs' have considerable tasks to carry out for the advancement of innovation in Malaysian firms. SMEs offer substantial contributions to the manufacturing sector in developing economies as well, as they are involved in 90 to 95 percent of all industrial ventures (Valaei, Rezaei and Emami, 2016). SMEs thus potentially impact the growth and innovation of Malaysia (Ibrahim and Heng, 2015).

Therefore, the transformation of SMEs is crucial to support Malaysia's strategies to become a high-income developed nation on par with first world countries. It is essential for SMEs to radically shift into higher gear in this sophisticated knowledge-based economy and achieve global recognition (Durst and Edvardsson, 2012).

\subsection{Knowledge Management}

The knowledge-based view articulates that a firm is considered a repository of knowledge, and the competitive advantage of a firm is ultimately earned through its ability to exploit and explore knowledge (Grant, 1996; Spender, 1996; Nonaka et al., 2000).

The construct of knowledge management strategy is explained through a number of dimensions or processes. According to previous studies, the dimensions of knowledge 
management strategy are human orientation and system orientation (Choi and Lee, 2002; Cohen and Olsen, 2014), codification and personalization (Hansen, Nohria and Tierney, 1999), knowledge absorption and knowledge exploitation (Roxas, Battisti and Deakins, 2013) and construction, embodiment and deployment (Wei, Choy and Chew, 2011). These KM strategy dimensions are generally recognized as parts of a process involving different sets of knowledge functions (Wei et al., 2011; Wu and Chen, 2014). Table 1 presents the sub-processes of KM strategy.

Table 1. KM Strategy and Sub-processes

\begin{tabular}{|c|c|c|}
\hline Study & KM Strategy & Sub-Processes \\
\hline Choi and Lee (2002) & System Orientation & $\begin{array}{ll}\text { - } & \text { Codification Knowledge } \\
\text { - } & \text { Storing knowledge } \\
\text { - } & \text { Acquiring Knowledge } \\
\text { - } & \text { Sharing Knowledge }\end{array}$ \\
\hline \multicolumn{3}{|l|}{ Cohen and Olsen, 2014} \\
\hline & Codification & - $\quad$ Storing Knowledge \\
\hline $\begin{array}{l}\text { Hansen, Nohria and Tierney } \\
\text { (1999) }\end{array}$ & Personalization & $\begin{array}{l}\text { - } \quad \text { Sharing Knowledge } \\
\text { - } \quad \text { Transferring Knowledge }\end{array}$ \\
\hline \multirow{3}{*}{$\begin{array}{l}\text { Roxas, Battisti and Deakins } \\
\text { (2013) }\end{array}$} & Absorption & $\begin{array}{ll}\text { - } & \text { Identification Knowledge } \\
\text { - } & \text { Acquisition Knowledge }\end{array}$ \\
\hline & Exploitation & $\begin{array}{l}\text { - Utilization Knowledge } \\
\text { - Assimilation Knowledge } \\
\text { - } \quad \text { Transformation Knowledge }\end{array}$ \\
\hline & Construction & $\begin{array}{l}\text { - } \text { Generating Knowledge } \\
\text { - } \quad \text { Creating Knowledge }\end{array}$ \\
\hline \multirow[t]{2}{*}{ Wei, Choy and Chew (2011) } & Embodiment & $\begin{array}{l}\text { - Documenting and Codifying } \\
\text { individuals' Knowledge }\end{array}$ \\
\hline & Deployment & - Disseminating Knowledge \\
\hline
\end{tabular}

Individual employees' tacit knowledge is vital in the increasingly turbulent environment of the global marketplace. It is difficult to transfer the tacit knowledge of an individual employee; it necessitates the management of knowledge (Kiessling et al., 2009), which principally integrates the specialized knowledge of a group of employees and entities of an organization (Grant, 1996). In fact, the learning process commences at the individual level and expands through a firm's routines and social contexts (Nonaka and Takeuchi, 1995). It 
ultimately spreads throughout the firm when knowledge is managed efficiently (Gold, Malhotra and Segars, 2001).

The literature has revealed the nature of humans as knowledge holders, because humans are natural amalgamations of subjective feelings such as fellowship, belief in goodness, compassion, loyalty, truth and magnificence (Kogut and Zander, 1996). Merat and Bo (2013) added that, in this regard, every individual plays a crucial role in producing their reality. Human emotions thus affect the ability of a team of knowledge workers to exploit their members' knowledge to influence their team performance (Kayes, 2004). Indeed, it is difficult to extract the valuable knowledge (tacit specialist knowledge) held by employees, implying that knowledge workers are essential players in firms, especially in knowledge-based firms that view knowledge as their principal resource. This has expanded the focus on the role of human resources and human aspects of an organization, including the role of leadership. Thus, this perspective intensifies the importance of leadership for KM in a firm (Merat and Bo, 2013).

\subsection{Leadership or Management?}

It is crucial to not just understand but also differentiate the concepts of leadership and management, since some scholars view leadership as a part of management. The relationship between leadership and management varies across researchers, as some believe both disciplines to be different while some perceive them to be one and the same. Kouzes and Posner (2002) distinguished both disciplines, stating that management is related to analytical activity focusing on objectives whereas leadership is related to creative activities and visions. Mladkova (2012) also emphasized that both leadership and management are different disciplines. She added that everyday management needs a leadership approach to have a greater impact, particularly when collaborating with knowledge workers.

Leadership is viewed as "the ability to influence the behavior of others to align their goals with the leader" (Liu and Fang, 2006). In relation to the role of leadership in KM initiatives, Singh (2008) indicated that if leaders set an example for others in the organization, they have an immediate influence on KM processes. Similarly, Skyrme and Amidon (1997) found that leaders who demonstrate a culture of openness to feedback and who use effective communication with employees are perceived by employees as leaders who are supportive of KM.

Similarly, Anantatmula (2008) asserted the vital role of leadership to develop and manage knowledge in firms. This is because promoting innovation via KM requires a collaborative culture as well as participation from members in decision-making processes. Leadership creates vision, and thereby provides a strategic direction for innovation efforts. Leaders also build relationships among employees that enhance both cooperation and resource exchange (Day, 2001). The relationship between a learning environment and KM effectiveness is therefore influenced by effective leadership (Singh, 2008).

Hence, organizations can leverage leadership to enhance their creative capability and sustain 
their competitive advantage in a dynamic environment. For SMEs in particular, choosing the right leadership style is imperative for KM. In this context, transformational leadership has been found to be useful to stimulate creativity and radical changes, as it creates an atmosphere that enhances followers' performance beyond individual self-interest (Donate and Sánchez de Pablo, 2015). For this reason, this paper addresses transformational leadership as an important driver of KM strategy in SMEs. Nevertheless, the effect of other leadership styles (i.e. transactional, servant, paternal, facilitative, and collaborative) on KM should also be examined in various settings. Thus, the central questions explored in this paper are:

i. What leadership style is apt to promote KM strategy within SMEs?

ii. Why is the particular leadership style appropriate in SMEs?

Table 2 delineates the summary of previous studies on leadership styles and KM. The following section discusses the specific leadership styles.

Table 2. Summary of Leadership Styles and KM

\begin{tabular}{|c|c|c|c|c|c|c|c|c|c|c|c|c|c|c|}
\hline & & \multicolumn{8}{|c|}{ KMP } & \multicolumn{5}{|c|}{ Leadership Styles } \\
\hline Author(s)/ Year & 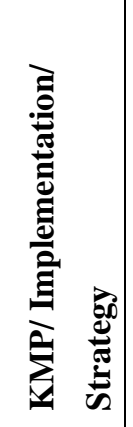 & : & 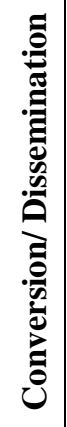 & 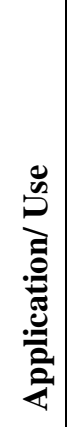 & 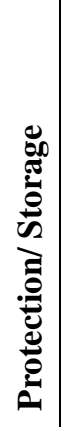 & 我 & 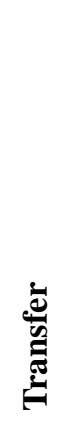 & • & 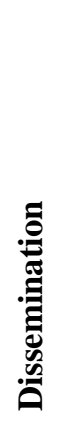 & 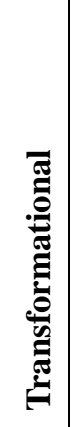 & 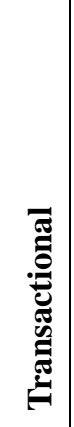 & 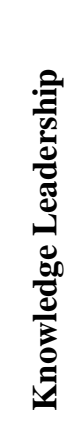 & 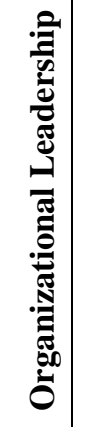 & $\stackrel{\grave{\Phi}}{\bar{\Xi}}$ \\
\hline $\begin{array}{l}\text { Yin, Ma, Yu, Jia and Liao } \\
\text { (2019) }\end{array}$ & & & & & & $x$ & & & & $x$ & & & & \\
\hline Mishra and Pandey (2019) & & & & & & $x$ & & & & $x$ & $x$ & & & $x$ \\
\hline AlShamsi and Ajmal (2019) & & & & & & $x$ & & & & & & & $x$ & \\
\hline Le and Lei (2019) & & & & & & $x$ & & & & $x$ & & & & \\
\hline $\begin{array}{l}\text { Saide, Indrajit, Trialih, } \\
\text { Ramadhani and Najamuddin } \\
\text { (2019) }\end{array}$ & $x$ & & & & & & & & & & & & & $x$ \\
\hline $\begin{array}{l}\text { Bertoldi, Giachino, Rossotto } \\
\text { and Bitbol-Saba (2018) }\end{array}$ & $x$ & & & & & & & & & & & $x$ & & \\
\hline
\end{tabular}




\begin{tabular}{|c|c|c|c|c|c|c|c|c|c|c|c|c|c|c|}
\hline & & \multicolumn{8}{|c|}{ KMP } & \multicolumn{5}{|c|}{ Leadership Styles } \\
\hline Author(s)/ Year & 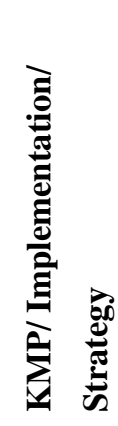 & 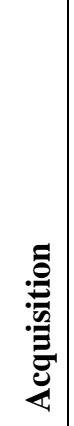 & 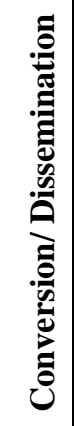 & 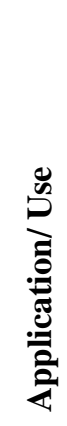 & 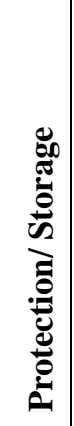 & क्ष & 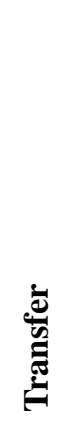 & Uี & 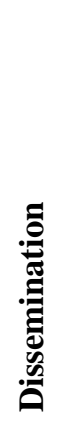 & 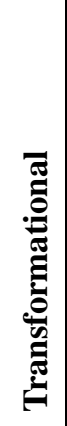 & 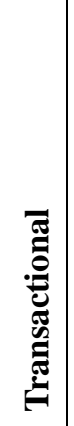 & 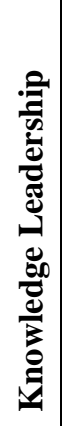 & 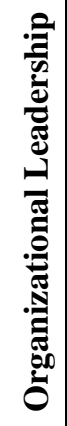 & $\stackrel{\grave{d}}{\grave{0}}$ \\
\hline Lee, Jang and Lee (2018) & & & & & & $x$ & & & & & & & & $x$ \\
\hline $\begin{array}{l}\text { Jahmani, Fadiya, Abubakar and } \\
\text { Elrehail (2018) }\end{array}$ & $x$ & & & & & & & & & & & & & $x$ \\
\hline $\begin{array}{l}\text { Al Dari, Jabeen and } \\
\text { Papastathopoulos (2018) }\end{array}$ & & & & & & $x$ & & & & & & & $x$ & \\
\hline $\begin{array}{l}\text { Valaei, Nikhashemi, Javan } \\
\text { (2017) }\end{array}$ & & $x$ & $x$ & $x$ & $x$ & & & & & $x$ & & & & \\
\hline AlShamsi and Ajmal (2018) & & & & & & $\mathbf{x}$ & & & & & & & $x$ & \\
\hline $\begin{array}{l}\text { Xiao, Zhang and Ordo' ñez de } \\
\text { Pablos (2017) }\end{array}$ & & & & & & $\mathbf{x}$ & & & & $x$ & & & & \\
\hline $\begin{array}{l}\text { Imran, Ilyas, Aslam and } \\
\text { Ubaid-Ur-Rahman (2016) }\end{array}$ & & $\mathbf{x}$ & $x$ & $x$ & & & & & & $x$ & & & & \\
\hline $\begin{array}{l}\text { Masa'deh, Obeidat and Tarhini } \\
\text { (2016) }\end{array}$ & & & & & & $x$ & & & & $x$ & $x$ & & & \\
\hline $\begin{array}{l}\text { Choi, Kim, Ullah and Kang } \\
\text { (2016) }\end{array}$ & & & & & & $x$ & & & & $x$ & & & & \\
\hline Chu (2016) & $x$ & & & & & & & & & & & $x$ & & \\
\hline $\begin{array}{l}\text { Bradshaw, Chebbi \& Otzel } \\
\text { (2015) }\end{array}$ & & & & & & $x$ & & & & $x$ & $\mathbf{x}$ & & & \\
\hline $\begin{array}{l}\text { Donate and. Sánchez de Pablo } \\
\text { (2015) }\end{array}$ & & & & $x$ & $\mathbf{x}$ & & $x$ & $\mathbf{x}$ & & & & $x$ & & \\
\hline Birasnav (2014) & & $\mathbf{x}$ & & $\mathbf{x}$ & & & $\mathbf{x}$ & & & $x$ & & & & \\
\hline $\begin{array}{l}\text { Gelard, Boroumand and } \\
\text { Mohammadi (2014) }\end{array}$ & & & & $x$ & $\mathbf{x}$ & & $x$ & $\mathbf{x}$ & & $x$ & & & & \\
\hline Lee, Lee and Park (2014) & & & & & & $x$ & & & & & & & & $x$ \\
\hline Yang, Huang \& Hsu (2014) & & $x$ & & $x$ & $x$ & $x$ & & & & & & $x$ & & \\
\hline $\begin{array}{l}\text { Ramachandran, Chong and } \\
\text { Wong (2013) }\end{array}$ & $x$ & & & & & & & & & & & & $x$ & \\
\hline $\begin{array}{l}\text { Birasnav, Albufalasa and Bader } \\
\text { (2013) }\end{array}$ & & $\mathbf{x}$ & & $x$ & & & $x$ & & & $x$ & & & & \\
\hline
\end{tabular}




\begin{tabular}{|c|c|c|c|c|c|c|c|c|c|c|c|c|c|c|}
\hline & & \multicolumn{8}{|c|}{ KMP } & \multicolumn{5}{|c|}{ Leadership Styles } \\
\hline Author(s)/ Year & 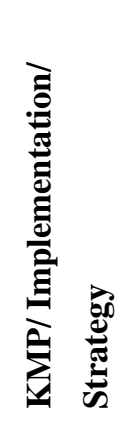 & : & 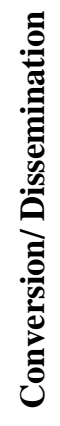 & 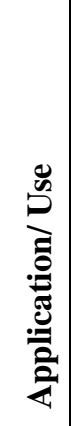 & 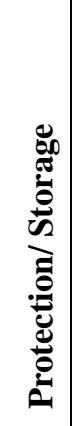 & 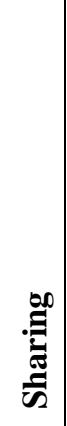 & 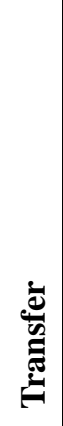 & : & 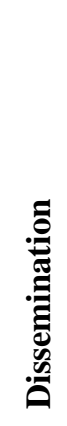 & 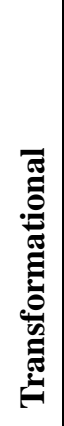 & 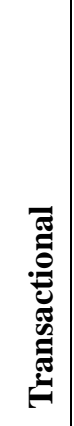 & 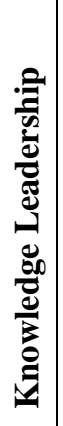 & 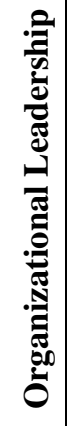 & 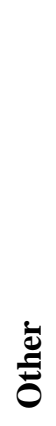 \\
\hline $\begin{array}{l}\text { Noruzy, Dalfard, Azhdari, } \\
\text { Nazari-Shirkouhi and } \\
\text { Rezazadeh (2013) }\end{array}$ & $x$ & & & & & & & & & $\boldsymbol{x}$ & & & & \\
\hline $\begin{array}{l}\text { Analoui, Doloriert and } \\
\text { Sambrook (2013) }\end{array}$ & & & & $x$ & $x$ & $x$ & & $\mathbf{x}$ & $x$ & x & $x$ & & & $x$ \\
\hline Song, Kolb, Lee, Kim (2012) & & & & & & & & $x$ & & $x$ & & & & \\
\hline Williams (2012) & $x$ & & & & & & & & & & & & $x$ & \\
\hline $\begin{array}{l}\text { Pinho, Rego and Pina e Cunha } \\
\text { (2012) }\end{array}$ & & $x$ & & & & $x$ & $x$ & $x$ & & & & & $\boldsymbol{x}$ & \\
\hline $\begin{array}{l}\text { Birasnav, Rangnekar and } \\
\text { Dalpati (2011) }\end{array}$ & $x$ & & & & & & & & & $x$ & & & & \\
\hline Nguyen and Mohamed (2011) & $x$ & & & & & & & & & $x$ & $x$ & & & \\
\hline Xue, Bradley and Liang (2011) & & & & & & $x$ & & & & & & & & $x$ \\
\hline Handzic (2011) & $x$ & & & & & & & & & & & & $x$ & \\
\hline Tung and Chang (2011) & & & & & & $x$ & & & & & & & & $x$ \\
\hline $\begin{array}{l}\text { Jayasingam, Ansari and Jantan } \\
\text { (2010) }\end{array}$ & & $x$ & & $x$ & & & & & $x$ & & & & & $x$ \\
\hline $\begin{array}{l}\text { Anantatmula and Kanungo } \\
\text { (2010) }\end{array}$ & $\mathbf{x}$ & & & & & & & & & & & & $x$ & \\
\hline Garrity (2010) & $x$ & & & & & & & & & & & & & 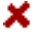 \\
\hline
\end{tabular}

\subsubsection{Transformational Leadership}

Bass (1999) defined transformational leadership as "a process by which leaders inspire their followers to perform at a higher level than expected and to potentially exceed the followers' own self interests for a high-level of shared vision".

An early conceptualization of transformational leadership theory identified three elements of transformational leaders that influence followers: (a) charisma, (b) individualized consideration, and (c) intellectual stimulation because the scholars in their literature often highlighted charismatic leadership as combined idealized influence and inspirational motivation behaviors (Avolio, Bass, \& Jung, 1999). After a series of studies by Bass and 
Avolio (1993) and Birasnav et al. (2011), transformational leadership was redefined into four elements, namely: (a) individualized consideration, (b) idealized influence, (c) intellectual stimulation, and (d) inspirational motivation. Individualized consideration places leaders as mentors for their followers who treat each employee differently and provide equal opportunities to all employees. Idealized influence views leaders as role models who develop a vision for firms and follow ethical principles in supporting employees to work efficiently and participate in risk-taking activities in turbulent atmospheres (Nemanich and Keller, 2007). Meanwhile, leaders' intellectual stimulation involves the cultivation of employees' intelligence to analyze and solve work problems in new and creative ways instead of using traditional techniques. Finally, inspirational motivation pertains how leaders motivate and inspire their workers to achieve desired organizational objectives (Bass and Riggo, 2006). With these elements, transformational leadership changes individuals from being self-interested to focusing on organizational interests (Theodore, 2013). It also emphasizes the satisfaction of basic employee needs to inspire followers to improve their work practices and work environment, so that the organization may perform beyond expectations (Ghasabeh, Soosay and Reaiche, 2015).

\subsubsection{Transactional Leadership}

According to Bono and Judge (2004), transactional leadership is a procedure aimed to control and monitors the workforce through rational or economic means. Transactional leaders also guide their followers to achieve established goals by clarifying the latter's roles and task requirements (Robbins and Judge, 2013). This leadership style consists of three dimensions: (a) contingent rewards, (b) management by exception-active, and (c) management by exception-passive (Bono and Judge, 2004). Contingent rewards essentially illustrate the exchange of resources, whereby leaders offer tangible and intangible rewards to subordinates in return for their performance. Management by exception-active involves monitoring subordinates' performance as well as correcting their actions when required. On the contrary, management by exception-passive involves leaders taking a passive approach, intervening only when a major problem occurs (Bono and Judge, 2004).

Leadership primarily utilized the transactional style until the late 1970s, concentrating on a managerial reward-punishment approach. However, this approach later shifted to the transformational style (Vandenabeele, 2014) due to certain limitations of transactional leadership. Transactional leadership does not consider the complexity and diversity of intelligence, passion, and task difficulty among employees. Transactional leaders also depend on a one-way approach, which hinders creativity or new knowledge creation from the ideas of others or themselves. Further, this leadership style leads to frustration, insecurity, and dissatisfaction among subordinates because leaders focus only on the task and not on subordinates' well-being (Odumeru and Ogbonna, 2013).

\subsubsection{Servant Leadership}

Robert K. Greenleaf initiated the theory of servant leadership in the time of modern 
organizational theory, and stated that "the servant-leader is servant first" (Correia de Sousa and van Dierendonck, 2010). According to van Dierendonck (2011), there is no unanimity in the definition of servant leadership. He added that previous works on servant leadership have used different models with up to 44 characteristics, which can be grouped into six key elements: Interpersonal Acceptance, Humility, Authenticity, Empowering and Developing People, Stewardship, and Providing Direction. Greenleaf has underscored that a key aspect of servant leadership is "going beyond one's self interest" (van Dierendonck, 2011). As such, servant leadership is perhaps of pertinence to the current era as it adds the element of social responsibility to leadership (Graham, 1991). Contrary to other leadership theories, it also unequivocally accentuates the needs of followers. Despite the fact that influence is commonly considered the key feature of leadership, servant leadership stands apart from other leadership theories by transforming the focal point of this influence into the idea of service from the leader to the follower (van Dierendonck, 2011).

Overall, the personal development of followers is the fundamental aspiration of this leadership style. Servant leaders create and seek opportunities to help and develop their followers because they are genuinely concerned about the wellbeing of their followers as opposed to the wellbeing of their organization, the latter being the ultimate goal of other leadership styles (Stone, Russell and Patterson, 2004).

Van Dierendonck (2011) noted that the four components of transformational leadership (individualized consideration, idealized influence, intellectual stimulation, and inspirational motivation) are complementary and comparable to servant leadership definitions as they indicate a similar concern for the development of followers. However, the idealized influence element of transformational leadership raises the question of for what and for whom followers grow. Further, according to Birasnav (2014), the individualized consideration element transforms leaders into mentors for their followers who support them by providing equal opportunity and care to every follower. This ultimately differentiates servant leadership and transformational leadership, such that transformational leaders focus on the organization (Graham, 1991) by paying attention to the personal development of followers so they perform better for the organization's advantage. In short, the objective of transformational leadership is to achieve high performance through employees' wellbeing (Bass, 1990).

\subsubsection{Paternalistic Leadership}

Paternalistic leadership is defined as "a style that combines strong discipline and authority with fatherly benevolence" (Farh and Cheng, 2000, p.91). It is divided into three components: (a) authoritarianism, (b) morality and (c) benevolence (Chen et al., 2014; Pellegrini and Scandura, 2008). Authoritarianism refers to leaders' behavior that demands compliance, obedience and respect as well as behavior that exhibits authority and control over followers (Cheng et al., 2004; Farh and Cheng, 2000). Morality is portrayed by leaders who do not exploit their sovereignty for personal benefit, and who exhibit unselfish and upstanding personal qualities (Chen et al., 2014; Pellegrini and Scandura, 2008). Benevolence involves a leader's individualized and comprehensive concern for their follower's welfare (Wang and 
Cheng, 2010). Specifically, leaders regulate their employees through rules, responsibilities, rewards and punishments, and subsequently show benevolence when followers obey them (Cheng et al., 2014).

Transformational leadership is distinct from paternalistic leadership. According to Bass and Bass (2009), the key inspirational technique of transformational leadership is the development of followers into leaders. Transformational leaders also communicate a vision, engage followers, intellectually challenge followers, and positively motivate followers at an emotional level (Bass and Avolio, 1993). Conversely, paternalistic leaders do not engage followers, communicate with followers, or delegate their vision since followers are expected to obey their leaders' decisions without hesitation (Pellegrini, Scandura, and Jayaraman, 2010). Therefore, paternalistic leaders play a 'father' role by guaranteeing the protection and wellbeing of their employees in exchange for conformity and loyalty (Pellegrini and Scandura, 2008).

\subsubsection{Facilitative Leadership}

Facilitative leadership behavior illustrates the extent to which a leader is approachable, democratic, and friendly towards his or her followers (House and Dessler, 1974). According to Sarin and McDermott (2003), facilitative leadership comprises two elements: (a) consideration and (b) participation. Consideration refers to leaders' concern for the wellbeing of team members, whereas participation refers to leaders' encouragement of their followers to take part in the decision making process and to collaborate for the creation of new ideas. Facilitative leaders challenge team members and support their opinions and ideas (Sarin et al., 2003). They also serve as mentors and coaches to encourage, empower and build their followers. According to Amy (2008), to gain competitive advantages, leaders should learn collaboration, networking, interpersonal influence skills, and empathy. Consistent with this, scholars perceive facilitative leadership to be effective in inducing transformation in complex circumstances.

Facilitative leadership is not a new idea; it generally explains the responsibility of leaders to create positive working relationships among employees (Fryer, 2012). Pirola-Merlo et al. (2002) argued that facilitative leadership is fundamentally related to the transformational leadership style, which also promotes a positive working environment for team members. In addition, Hirst et al. (2004) articulated that facilitative leadership has a similar approach as transformational leadership in terms of supporting ideas and opinions as well as encouraging respect and productive conflict resolution. Besides that, Watt (2009) claimed that the facilitative leadership theory is adapted from the transformational leadership theory, as both empower followers to encounter challenges emerging from internal or external turbulent environments.

\subsubsection{Collaborative Leadership}

Collaborative leadership involves equipping and connecting an entire group of members by: (a) structuring productive processes for cooperation, (b) organizing suitable stakeholders and 
(c) encouraging and supporting stakeholders' interactions (Archer and Cameron, 2009). As collaborative leaders work through partnerships, alliances and networks, they safeguard the primary interests and processes of each stakeholder group through shared leadership as opposed to unilateral action on their part.

Ardoin et al. (2014) stated that collaborative leadership promotes a less hierarchical and more egalitarian approach to influence followers. Consequently, these leaders practice open processes, shared decision making, and joint problem solving to engage people. They also encourage creativity and innovative problem solving. Collaborative leadership is thus not limited by a unidirectional flow of influence on followers because it works in a less formalized environment (Fletcher and Kaufer, 2003). This leadership style shifts leaders' characteristics to their practices, i.e. from 'who leaders are' to 'what leaders do'. Archer and Cameron (2009) outlined that to implement collaborative leadership in firms, three criteria should be fulfilled: (1) the ability to rapidly structure new coalitions, even with organizations that have been historically disliked or distrusted; (2) the ability to restore broken relationships with stakeholders; and (3) the ability to rectify inevitable conflicts.

Ardoin et al. (2014) posited that the attributes of transformational and collaborative leadership are similar because both styles emphasize a 'shared goals' orientation. Collaborative leadership also encourages bidirectional learning, consistent with transformational leadership that employs inspiration, intellectual stimulation, and charisma to promote communication and establish organizational learning (Conger, 1999).

Table 3 shows the summary of leadership styles discussed in the sections above.

Table 3. Summary of Leadership Styles

\begin{tabular}{|c|c|c|c|c|c|}
\hline $\begin{array}{l}\text { Transformational } \\
\text { Leadership }\end{array}$ & $\begin{array}{l}\text { Transactional } \\
\text { Leadership }\end{array}$ & $\begin{array}{l}\text { Servant } \\
\text { Leadership }\end{array}$ & $\begin{array}{l}\text { Paternalistic } \\
\text { Leadership }\end{array}$ & $\begin{array}{l}\text { Facilitative } \\
\text { Leadership }\end{array}$ & $\begin{array}{l}\text { Collaborative } \\
\text { Leadership }\end{array}$ \\
\hline $\begin{array}{l}\text { Transformational } \\
\text { leaders ready to } \\
\text { discuss with } \\
\text { employees about } \\
\text { plans before } \\
\text { execution. }\end{array}$ & $\begin{array}{l}\text { Transactional } \\
\text { leaders do not } \\
\text { feel easy to } \\
\text { discuss with } \\
\text { employees } \\
\text { about plans. }\end{array}$ & $\begin{array}{l}\text { Servant } \\
\text { leadership } \\
\text { emphasizes } \\
\text { increased service } \\
\text { to others, } \\
\text { including } \\
\text { employees, } \\
\text { customers, and } \\
\text { community, as } \\
\text { the chief priority. }\end{array}$ & $\begin{array}{l}\text { The leader } \\
\text { assumes s the } \\
\text { role of the } \\
\text { parent, the } \\
\text { father who } \\
\text { knows best. }\end{array}$ & $\begin{array}{l}\text { Believe in the } \\
\text { principles of } \\
\text { collaboration } \\
\text { and } \\
\text { participation. }\end{array}$ & $\begin{array}{l}\text { Collaborative } \\
\text { leaders work } \\
\text { through } \\
\text { alliances, } \\
\text { coalitions and } \\
\text { partnerships. }\end{array}$ \\
\hline $\begin{array}{l}\text { Employees } \\
\text { complete goal } \\
\text { through superior } \\
\text { principles and } \\
\text { ethics. }\end{array}$ & $\begin{array}{l}\text { Leader set } \\
\text { rewards and } \\
\text { punishments } \\
\text { for employees } \\
\text { to accomplish } \\
\text { the goal. }\end{array}$ & $\begin{array}{l}\text { Holistic } \\
\text { approach to work } \\
\text { that encourages a } \\
\text { sense of } \\
\text { community and } \\
\text { shared }\end{array}$ & $\begin{array}{l}\text { Look after, } \\
\text { nurture, guide, } \\
\text { protect, and } \\
\text { behave } \\
\text { generally like a } \\
\text { father would }\end{array}$ & $\begin{array}{l}\text { Possess and } \\
\text { use high-level } \\
\text { interpersonal } \\
\text { skills like } \\
\text { active } \\
\text { listening, }\end{array}$ & $\begin{array}{l}\text { Focuses on the } \\
\text { mutual influence } \\
\text { among members } \\
\text { of a less } \\
\text { hierarchical, } \\
\text { more egalitarian }\end{array}$ \\
\hline
\end{tabular}




\begin{tabular}{|c|c|c|c|c|c|}
\hline & & $\begin{array}{l}\text { decision-making } \\
\text { power. }\end{array}$ & $\begin{array}{l}\text { behave toward } \\
\text { his } \\
\text { children-exhibit } \\
\text { s concern for } \\
\text { the } \\
\text { subordinates' } \\
\text { general } \\
\text { well-being. }\end{array}$ & $\begin{array}{l}\text { questioning, } \\
\text { and } \\
\text { paraphrasing } \\
\text { when } \\
\text { interacting } \\
\text { with others. }\end{array}$ & team. \\
\hline $\begin{array}{l}\text { Motivates } \\
\text { employees by give } \\
\text { priority to group } \\
\text { interests first. }\end{array}$ & $\begin{array}{l}\text { Motivates } \\
\text { employees by } \\
\text { tempting their } \\
\text { self interest. }\end{array}$ & $\begin{array}{l}\text { Linked to the } \\
\text { emotional } \\
\text { well-being of } \\
\text { employees. }\end{array}$ & $\begin{array}{l}\text { Tend not to } \\
\text { defer to the } \\
\text { subordinates' } \\
\text { wishes, but } \\
\text { instead } \\
\text { maintains a } \\
\text { sense of } \\
\text { hierarchy and } \\
\text { expect } \\
\text { obedience. }\end{array}$ & $\begin{array}{l}\text { Understand } \\
\text { how to build } \\
\text { and maintain } \\
\text { high } \\
\text { performance } \\
\text { teams. }\end{array}$ & $\begin{array}{l}\text { Similar in its } \\
\text { emphasis on a } \\
\text { 'shared goals' } \\
\text { orientation. }\end{array}$ \\
\hline $\begin{array}{l}\text { Works to } \\
\text { transform the } \\
\text { organizational } \\
\text { traditions by } \\
\text { implementing new } \\
\text { thoughts. }\end{array}$ & $\begin{array}{l}\text { Works } \\
\text { surrounded by } \\
\text { the } \\
\text { organizational } \\
\text { traditions. }\end{array}$ & $\begin{array}{l}\text { Going beyond } \\
\text { one's self } \\
\text { interest }\end{array}$ & $\begin{array}{l}\text { Paternalistic } \\
\text { leader } \\
\text { "interferes" } \\
\text { with the liberty } \\
\text { or autonomy of } \\
\text { the subordinate } \\
\text { without his or } \\
\text { her consent. }\end{array}$ & $\begin{array}{l}\text { Excellent } \\
\text { communicator } \\
\text { s who freely } \\
\text { share } \\
\text { information. }\end{array}$ & $\begin{array}{l}\text { Often involves } \\
\text { bidirectional } \\
\text { learning, } \\
\text { organizational } \\
\text { learning to } \\
\text { promote } \\
\text { intellectual } \\
\text { stimulation. }\end{array}$ \\
\hline $\begin{array}{l}\text { Individualized } \\
\text { reflection: Each } \\
\text { behavior is } \\
\text { intended for each } \\
\text { person to convey } \\
\text { kindness and } \\
\text { support. }\end{array}$ & $\begin{array}{l}\text { Management-b } \\
\text { y-exception: } \\
\text { continue the } \\
\text { status quo; } \\
\text { pressure } \\
\text { correct actions } \\
\text { to recover } \\
\text { performance. }\end{array}$ & & & $\begin{array}{l}\text { Operate } \\
\text { without status } \\
\text { or rank } \\
\text { consciousness. } \\
\text { Actively } \\
\text { engage in } \\
\text { giving and } \\
\text { receiving } \\
\text { feedback. }\end{array}$ & \\
\hline $\begin{array}{l}\text { Intellectual } \\
\text { stimulation: } \\
\text { support new and } \\
\text { creative ideas to } \\
\text { solve problems. }\end{array}$ & & & & $\begin{array}{l}\text { Train and } \\
\text { coach their } \\
\text { people, } \\
\text { manage } \\
\text { conflict and } \\
\text { mediate } \\
\text { disputes } \\
\text { skillfully. }\end{array}$ & \\
\hline
\end{tabular}




\section{Why Transformational Leadership?}

The characteristics of transformational leaders are relevant to knowledge management studies (Bass, 1990; Bass and Avolio, 1993) because organizations foster innovation and creativity through transformational leaders who: (1) stimulate followers' intellectual abilities (i.e. intelligence, knowledge, rationality, and problem solving); (2) encourage followers' organizational learning and skill development by promoting discussions, reviews and open sharing of ideas for knowledge development (Von Krogh, Nonaka and Rechsteiner, 2012); and (3) promote greater organizational goals that engage high-quality knowledge to solve complex and novel tasks (Von Krogh, Nonaka and Rechsteiner, 2012). Therefore, Bradshaw, Chebbi and Oztel (2015) advocate that transformational leadership is the most relevant leadership style for effective knowledge management.

According to Ramadass, Sambasivan and Xavier (2017), although researchers have criticized transformational leadership, this style has several merits. The distinct merits of transformational leadership highlighted by empirical studies are: (1) emphasis on common vision; (2) support of changes; and (3) effectiveness at organizational, industrial and national levels (Lee, 2014). Transformational leadership is proactive and motivates employees to perform beyond expectations (Camps and Rodriguez, 2011). Though individual employees develop knowledge, it is the work environment, through leadership, that plays a significant role in evolving knowledge. Thus, firms would best leverage the diverse elements of knowledge by having the right leader (Birasnav, 2014; Birasnav, 2013). In addition, researchers surmise that organizations would be successful with leaders who are able to influence and motivate their employees to accrue and extend their knowledge to go beyond organization goals (Alsalami, Behery, and Abdullah, 2014).

Therefore, transformational leadership is the most appropriate leadership approach in the context of the KM of SMEs for three reasons, as explained by Matzler et al. (2008). First, SME entrepreneurs play important leadership roles as top management. SME owners/managers generally decide the vision and direction (idealized influence) of the firm, and are able to communicate their goals with their followers personally (inspiration, individualized consideration). Second, intrinsic motivation is a useful tool in SMEs since they have limited resources and financial leeway (extrinsic motivation). Although financial rewards work to align the actions of the employees, intrinsic motivation from leaders may have greater impacts on employees' knowledge development and sharing. Hurley (2011) also emphasized that an administrative reward system discourages collaboration among employees. Third, leaders should be flexible because of the dynamic environment in which SMEs operate. Thus, flexible leaders (e.g. transformational leaders who reward intellectual curiosity and risk taking) would be effective for SMEs (Matzler et al., 2008). Scholars propose that leadership behavior is vital for SMEs' organizational knowledge and performance (Nguyen and Mohamed, 2011; Obiwuru et al., 2011). Therefore, based on the theoretical discussion above, there is a need to empirically investigate the impact of transformational leadership on KM strategy in SMEs. 


\section{Conclusion}

Managing knowledge is crucial to creating sustainable competitive advantage. Leaders are principal to creating cultures, systems and structures that foster knowledge management and knowledge exploitation (Bryant, 2003). Thus, this conceptual paper sought to review and compare six leadership styles in relation to KM strategy in SMEs. It addresses the gap in previous studies that have solely examined 'what' leadership style influences KM strategy but have largely overlooked 'why' a particular leadership style is more effective for KM strategy, specifically in SMEs. Based on theoretical justifications, this paper concludes that transformational leadership is most appropriate leadership style to cultivate $\mathrm{KM}$ in the context of SMEs.

This paper serves as a foundation for evaluating the impact of leadership styles on KM strategy in SMEs. Therefore, future studies are recommended to empirically verify this paper's propositions with valid research methods to determine if transformational leadership does indeed promote KM strategy in Malaysian SMEs.

\section{References}

Al Dari, T., Jabeen, F., \& Papastathopoulos, A. (2018). Examining the role of leadership inspiration, rewards and its relationship with contribution to knowledge sharing. Journal of Workplace Learning, 30(6), 488-512. https://doi.org/10.1108/JWL-11-2017-0105

Alsalami, E., Behery, M., \& Abdullah, S. (2014). Transformational leadership and its effects on organizational learning and innovation: evidence from Dubai. Journal of Applied Management and Entrepreneurship, 19(4), 61-81.

AlShamsi, O. M., \& Ajmal, M. M. (2019). Knowledge sharing in technology-intensive manufacturing organizations. Business Process Management Journal, 25(5), 802-824. https://doi.org/10.1108/BPMJ-07-2017-0194

AlShamsi, O., \& Ajmal, M. (2018). Critical factors for knowledge sharing in technology-intensive organizations: evidence from UAE service sector. Journal of Knowledge Management, 22(2), 384-412. https://doi.org/10.1108/JKM-05-2017-0181

Amy, A. H. (2008). Leaders as facilitators of individual and organizational learning. Leadership \& Organization Development Journal,29(3), 212-234. https://doi.org/10.1108/01437730810861281

Analoui, B. D., Hannah Doloriert, C., \& Sambrook, S. (2013). Leadership and knowledge management in UK ICT organisations. Journal of Management Development, 32(1), 4-17. http://dx.doi.org/10.1108/02621711311286892

Anantatmula, V. S. (2008). Leadership role in making effective use of KM. VINE, 38(4), 445-460. http://dx.doi.org/10.1108/03055720810917705

Anantatmula, V. S., \& Kanungo, S. (2010). Modeling enablers for successful KM 
http://dx.doi.org/10.1108/13673271011015598

Archer, D., \& Cameron, A. (2009). Tough times call for collaborative leaders. Industrial and Commercial Training, 41(5), 232-237. https://doi.org/10.1108/00197850910974776

Ardoin, N. M., Gould, R. K., Kelsey, E., \& Fielding-Singh, P. (2015). Collaborative and transformational leadership in the environmental realm. Journal of Environmental Policy \& Planning, 17(3), 360-380. https://doi.org/10.1080/1523908X.2014.954075

Avolio, B. J., Bass, B.M., \& Jung, D. I. (1999). Re-examining the components of transformational and transactional leadership using the multi-factor leadership questionnaire. Journal of Occupational and Organizational Psychology, 72, 441-462. https://doi.org/10.1348/096317999166789

Barkema, H. G., Baum, J. A., \& Mannix, E. A. (2002). Management challenges in a new time. Academy of Management Journal, 45(5), 916-930. https://doi.org/10.2307/3069322

Bass, B. M. (1990). From transactional to transformational leadership: Learning to share the vision. Organizational 1ynamics, 18(3), https://doi.org/10.1016/0090-2616(90)90061-SGet rights and content

Bass, B. M. (1999). On the taming of charisma: A reply to Janice Beyer. The Leadership Quarterly, 10(4), 541-553. https://doi.org/10.1016/S1048-9843(99)00030-2

Bass, B. M., \& Bass, R. (2009). The Bass handbook of leadership: Theory, research, and managerial applications. Simon and Schuster.

Bass, B. M., \& Riggio, R. E. (2006). Transformational Leadership. Mahwah, NJ: L. I Lawrence Erlbaum.

Bass, B., \& Avolio, B. J. (1993). Improving organizational effectiveness through transformational leadership. Thousands Oaks, CA: Sage.

Bens, I. (2007). The ten essential processes of facilitative leaders. Global Business and Organizational Excellence, 26(5), 38-56. https://doi.org/10.1002/joe.20163

Bertoldi, B., Giachino, C., Rossotto, C., \& Bitbol-Saba, N. (2018). The role of a knowledge leader in a changing organizational environment. A conceptual framework drawn by an analysis of four large companies. Journal of Knowledge Management, 22(3), 587-602. https://doi.org/10.1108/JKM-09-2017-0422

Birasnav, M. (2013). Implementation of supply chain management practices: The role of transformational leadership. Global Business Review, 14(2), 329-342. https://doi.org/10.1177/0972150913477525

Birasnav, M. (2014). Knowledge management and organizational performance in the service industry: The role of transformational leadership beyond the effects of transactional 
http://dx.doi.org/10.1016/j.jbusres.2013.09.006

Birasnav, M., Albufalasa, M., \& Bader, Y. (2013). The role of transformational leadership and knowledge management processes on predicting product and process innovation: An empirical study developed in Kingdom of Bahrain. Tékhne, 11(2), 64-75. http://dx.doi.org/10.1016/j.tekhne.2013.08.001

Birasnav, M., Rangnekar, S., \& Dalpati, A. (2011). Transformational leadership and human capital benefits: The role of knowledge management. Leadership \& Organization Development Journal, 32, 106-126. http://dx.doi.org/10.1108/01437731111112962

Bono, J. E., \& Judge, T. A. (2004). Personality and transformational and transactional leadership: a meta-analysis. Journal of applied psychology,89(5), 901. https://doi.org/10.1037/0021-9010.89.5.901

Bradshaw, R., Chebbi, M., \& Oztel, H. (2015). Leadership and knowledge sharing. Asian Journal of Business Research ISSN, 1178(8933). https://doi.org/10.14707/ajbr.150001

Bryant, S. E. (2003). The role of transformational and transactional leadership in creating, sharing and exploiting organizational knowledge. Journal of Leadership \& Organizational Studies, 9(4), 32-44. http://dx.doi.org/10.1177/107179190300900403

Camps, J., \& Rodríguez, H. (2011). Transformational leadership, learning, and employability: Effects on performance among faculty members. Personnel Review, 40(4), 423-442. https://doi.org/10.1108/00483481111133327

Chen, X. P., Eberly, M. B., Chiang, T. J., Farh, J. L., \& Cheng, B. S. (2014). Affective trust in Chinese leaders: Linking paternalistic leadership to employee performance. Journal of management, 40(3), 796-819. https://doi.org/10.1177/0149206311410604

Cheng, B. S., Boer, D., Chou, L. F., Huang, M. P., Yoneyama, S., Shim, D., \& Tsai, C. Y. (2014). Paternalistic leadership in four East Asian societies: Generalizability and cultural differences of the triad model. Journal of Cross-Cultural Psychology,45(1), 82-90. https://doi.org/10.1177/0022022113490070

Cheng, B. S., Chou, L. F., Wu, T. Y., Huang, M. P., \& Farh, J. L. (2004). Paternalistic leadership and subordinate responses: Establishing a leadership model in Chinese organizations. Asian Journal of Social Psychology, 7(1), 89-117. https://doi.org/10.1111/j.1467-839X.2004.00137.x

Choi, B., \& Lee, H. (2002). Knowledge management strategy and its link to knowledge creation process. Expert Systems with applications, 23(3), 173-187. https://doi.org/10.1016/S0957-4174(02)00038-6

Choi, S. B., Kim, K., Ullah, S. E., \& Kang, S. W. (2016). How transformational leadership facilitates innovative behavior of Korean workers. Personnel Review, 45(3), 459-479. 
https://doi.org/10.1108/PR-03-2014-0058

Chu, K. W. (2016). Leading knowledge management in a secondary school. Journal of Knowledge Management, 20(5), 1104-1147. https://doi.org/10.1108/JKM-10-2015-0390

Cohen, J. F., \& Olsen, K. (2015). Knowledge management capabilities and firm performance: A test of universalistic, contingency and complementarity perspectives. Expert Systems with Applications, 42(3), 1178-1188. http://dx.doi.org/10.1016/j.eswa.2014.09.002

Conger, J. A. (1999). Charismatic and transformational leadership in organizations: An insider's perspective on these developing streams of research. The leadership quarterly, 10(2), 145-179. https://doi.org/10.1016/S1048-9843(99)00012-0

Correia de Sousa, M., \& van Dierendonck, D. (2010). Knowledge workers, servant leadership and the search for meaning in knowledge-driven organizations. On the Horizon, 18(3), 230-239. https://doi.org/10.1108/10748121011072681

Day, D. V. (2001). Leadership development: A review in context. The Leadership Quarterly, 11(4), 581-613. https://doi.org/10.1016/S1048-9843(00)00061-8

Donate, M. J., \& de Pablo, J. D. S. (2015). The role of knowledge-oriented leadership in knowledge management practices and innovation. Journal of Business Research,68(2), 360-370. http://dx.doi.org/10.1016/j.jbusres.2014.06.022

Durst, S., \& Edvardsson, I.R. (2012). Knowledge management in SMEs: a literature review. Journal of Knowledge Management, 16(6), 879-903. http://dx.doi.org/10.1108/13673271211276173

Farh, J. L., \& Cheng, B. S. (2000). A cultural analysis of paternalistic leadership in Chinese organizations. In Management and organizations in the Chinese context (pp. 84-127). Palgrave Macmillan UK.

Fletcher, J. K., \& Kaufer, K. (2003). Shared leadership: Paradox and possibility. In C. L. Pearce \& J. A. Conger (Eds.), Shared leadership: Reframing the hows and whys of leadership (pp. 21-47). Thousand Oaks, CA: Sage.

Fryer, M. (2012). Facilitative leadership: drawing on Jürgen Habermas' model of ideal speech to propose a less impositional way to lead. Organization, 19(1), 25-43. https://doi.org/10.1177/1350508411401462

Garrity, R. (2010). Future leaders: putting learning and knowledge to work. On The Horizon-The Strategic Planning Resource for Education Professionals, 18(3), 266-278. http://dx.doi.org/10.1108/10748121011072717

Gelard, P., Boroumand, Z., \& Mohammadi, A. (2014). Relationship between transformational leadership and knowledge management. International Journal of Information Science and Management, 12(2), 67-82. 
Ghasabeh, M. S., Soosay, C., \& Reaiche, C. (2015). The emerging role of transformational leadership. The Journal of Developing Areas, 49(6), 459-467. 10.1353/jda.2015.0090

Gold, A. H., Malhotra, A., \& Segars, A. H. (2001). Knowledge management: An organizational capabilities perspective. Journal of Management Information Systems, 18(1), 185-214. http://dx.doi.org/10.1080/07421222.2001.11045669

Graham, J. W. (1991). Servant-leadership in organizations: Inspirational and moral. The Leadership Quarterly, 2(2), 105-119. https://doi.org/10.1016/1048-9843(91)90025-W

Grant, R. M. (1996). Toward a knowledge-based theory of the firm. Strategic management journal, 17(S2), 109-122. https://doi.org/10.1002/smj.4250171110

Grant, R.M. \& Baden-Fuller, C. (2004). A knowledge accessing theory of strategic alliances. Journal of Management Studies, $\quad 41(1), \quad$ 61-84. https://doi.org/10.1111/j.1467-6486.2004.00421.x

Hale Öner, Z. (2012). Servant leadership and paternalistic leadership styles in the Turkish business context: A comparative empirical study. Leadership \& Organization Development Journal, 33(3), 300-316. http://dx.doi.org/10.1108/01437731211216489

Handzic, M. (2011). Integrated socio-technical knowledge management model: an empirical evaluation. Journal of Knowledge Management, 15(2), 198-211. https://doi.org/10.1108/13673271111119655

Hansen, M. T., Nohria, N., \& Tierney, T. (1999). What's your strategy for managing knowledge. The knowledge management yearbook 2000-2001, 77(2), 106-116.

Hirst, G., Mann, L., Bain, P., Pirola-Merlo, A., \& Richver, A. (2004). Learning to lead: The development and testing of a model of leadership learning. The Leadership Quarterly, 15(3), 311-327. https://doi.org/10.1016/j.leaqua.2004.02.011

House, R. J., \& Dessler, G. (1974). The Path Goal Theory of Leadership: Some Post Hoc and A Priori Tests' In JG Hunt and LL Larson (Eds.), Contingency Approaches to Leadership Carbon-dale, III.: Southern Illinois University Press.

Hurley, T. J. (2011). Collaborative Leadership: Engaging Collective Intelligence to Achieve Results across Organizational Boundaries. Oxford Leadership, 1-15.

Ibrahim, S., \& Heng, L. H. (2015). The roles of learning in stimulating knowledge sharing at SMEs. Procedia-Social and Behavioral Sciences, 172, 230-237. https:/doi.org 10.1016/j.sbspro.2015.01.359

Imran, M. K., Ilyas, M., Aslam, U., \& Ubaid-Ur-Rahman. (2016). Organizational learning through transformational leadership. The Learning Organization, 23(4), 232-248. https://doi.org/10.1108/TLO-09-2015-0053

Jahmani, K., Fadiya, S. O., Abubakar, A. M., \& Elrehail, H. (2018). Knowledge content 
quality, perceived usefulness, KMS use for sharing and retrieval. VINE Journal of Information and Knowledge Management Systems, 48(4), 470-490. https://doi.org/10.1108/VJIKMS-08-2017-0054

Jayasingam, S., Ansari, M. A., \& Jantan, M. (2010). Influencing knowledge workers: the power of top management. Industrial Management \& Data Systems, 110(1), 134-151. https://doi.org/10.1108/02635571011008443

Kayes, D. C. (2004). The 1996 Mount Everest climbing disaster: The breakdown of learning in teams. Human Relations, 57(10), 1263-1284. https://doi.org/10.1177/0018726704048355

Kiessling, T. S., Richey, R. G., Meng, J., \& Dabic, M. (2009). Exploring knowledge management to organizational performance outcomes in a transitional economy. Journal of world business, 44(4), 421-433. https:/doi.org/10.1016/j.jwb.2008.11.006

Kogut, B., \& Zander, U. (1996). What firms do? Coordination, identity, and learning. Organization science, 7(5), 502-518.

Kouzes, J. M., \& Posner, B. Z. (2006). The leadership challenge (Vol. 3). John Wiley \& Sons. Le, P. B., \& Lei, H. (2019). Determinants of innovation capability: the roles of transformational leadership, knowledge sharing and perceived organizational support. Journal of Knowledge Management, 23(3), 527-547. https://doi.org/10.1108/JKM-09-2018-0568

Lee, J. Y., Jang, S. H., \& Lee, S. Y. (2018). Paternalistic leadership and knowledge sharing with outsiders in emerging economies. Personnel Review, 47(5), 1094-1115. https://doi.org/10.1108/PR-03-2017-0068

Lee, J., Lee, H., \& Park, J. G. (2014). Exploring the impact of empowering leadership on knowledge sharing, absorptive capacity and team performance in IT service. Information Technology \& People, 27(3), 366-386. https://doi.org/10.1108/ITP-10-2012-0115

Lee, M. (2014). Transformational leadership: is it time for a recall? International journal of management and applied research, 1(1), 17-29. https://doi.org/10.18646/2056.11.14-002

Liu, A. M., \& Fang, Z. (2006). A power-based leadership approach to project management. Construction Management and Economics, 24(5), 497-507. https://doi.org/10.1080/01446190600567944

Masa'deh, R., Obeidat, B. Y., \& Tarhini, A. (2016). A Jordanian empirical study of the associations among transformational leadership, transactional leadership, knowledge sharing, job performance, and firm performance. Journal of Management Development, 35(5), 681-705. https://doi.org/10.1108/JMD-09-2015-0134

Matzler, K., Schwarz, E., Deutinger, N., \& Harms, R. (2008). The relationship between transformational leadership, product innovation and performancein SMEs. Journal of Small Business \& Entrepreneurship, 21(2), 139-151. 
Merat, A., \& Bo, D. (2013). Strategic analysis of knowledge firms: The links between knowledge management and leadership. Journal of Knowledge Management, 17(1), 3-15. https://doi.org/10.1108/13673271311300697

Mishra, M., \& Pandey, A. (2019). The impact of leadership styles on knowledge-sharing behavior: a review of literature. Development and Learning in Organizations: An International Journal, 33(1), 16-19. https://doi.org/10.1108/DLO-06-2018-0067

Mládková, L. (2012). Leadership in management of knowledge workers. Procedia-Social and Behavioral Sciences, 41, 243-250. https://doi.org/10.1016/j.sbspro.2012.04.028

Nemanich, L. A., \& Keller, R. T. (2007). Transformational leadership in an acquisition: A field study of employees. The Leadership Quarterly, 18(1), 49-68. https://doi.org/10.1016/j.leaqua.2006.11.003

Nguyen, H. N., \& Mohamed, S. (2011). Leadership behaviors, organizational culture and knowledge management practices: An empirical investigation. The Journal of Management Development, 30(2), 206-221. http://dx.doi.org/10.1108/02621711111105786

Nonaka, I. (1994). A dynamic theory of organizational knowledge creation. Organization science, 5(1), 14-37.

Nonaka, I., \& Takeuchi, H. (1995). The knowledge-creating company: How Japanese companies create the dynamics of innovation. Oxford university press.

Nonaka, I., Toyama, R., \& Nagata, A. (2000). A firm as a knowledge-creating entity: a new perspective on the theory of the firm. Industrial and corporate change, 9(1), 1-20. https://doi.org/10.1093/icc/9.1.1

Noruzy, A., Dalfard, V. M., Azhdari, B., Nazari-Shirkouhi, S., \& Rezazadeh, A. (2013). Relations between transformational leadership, organizational learning, knowledge management, organizational innovation, and organizational performance: an empirical investigation of manufacturing firms. The International Journal of Advanced Manufacturing Technology, 64, 1073-1085. https://doi.org/10.1007/s00170-012-4038-y

Obiwuru, T. C., Okwu, A. T., Akpa, V. O., \& Nwankwere, I. A. (2011). Effects of leadership style on organizational performance: A survey of selected small scale enterprises in Ikosi-Ketu council development area of Lagos State, Nigeria. Australian Journal of Business and Management Research, 1(7), 100-111.

Odumeru, J. A., \& Ogbonna, I. G. (2013). Transformational vs. transactional leadership theories: Evidence in literature. International Review of Management and Business Research, 2(2), 355-361.

Pellegrini, E. K., \& Scandura, T. A. (2008). Paternalistic leadership: A review and agenda for future research. Journal of management, 34(3), 566-593. https://doi.org/10.1177/0149206308316063 
Pellegrini, E. K., Scandura, T. A., \& Jayaraman, V. (2010). Cross-cultural generalizability of paternalistic leadership: An expansion of leader-member exchange theory. Group \& Organization Management, 35(4), 391-420. https://doi.org/10.1177/1059601110378456

Pinho, I., Rego, A., \& Pina e Cunha, M. (2012). Improving knowledge management processes: a hybrid positive approach. Journal of knowledge management, 16(2), 215-242. http://dx.doi.org/10.1108/13673271211218834

Pirola-Merlo, A., Härtel, C., Mann, L., \& Hirst, G. (2002). How leaders influence the impact of affective events on team climate and performance in $\mathrm{R} \& \mathrm{D}$ teams. The leadership quarterly, 13(5), 561-581. https://doi.org/10.1016/S1048-9843(02)00144-3

Ramachandran, S.D, Chong, S.C, \& Ismail, H. (2009). The practice of knowledge management processes: A comparative study of public and private higher education institutions in Malaysia. Vine, The journal of information and knowledge management systems 39(3), 203-222. https://doi.org/10.1108/03055720911003978

Ramadass, S. D., Sambasivan, M., \& Xavier, J. A. (2017). Critical factors in public sector collaboration in Malaysia: leadership, interdependence, and community. International Journal of Public Sector Management, 30(5). http://dx.doi.org/10.1108/IJPSM-10-2016-0167

Robbins, S. P., \& Judge, T. A. (2013). Organizational behavior, 15th Eden. Pearson Education Limited.

Roxas, B., Battisti, M., \& Deakins, D. (2014). Learning, innovation and firm performance: knowledge management in small firms. Knowledge Management Research \& Practice, 12(4), 443-453. http://hdl.handle.net/10536/DRO/DU:30057363

Saide, S., Indrajit, R. E., Trialih, R., Ramadhani, S., \& Najamuddin, N. (2019). A theoretical and empirical validation of information technology and path-goal leadership on knowledge creation in university. Journal of Science and Technology Policy Management, 10(3), 551-568. https://doi.org/10.1108/JSTPM-06-2018-0067

Saleh, A. S., \& Ndubisi, N. O. (2006). An evaluation of SME development in Malaysia. International review of business research papers, 2(1), 1-14.

Sarin, S., \& McDermott, C. (2003). The effect of team leader characteristics on learning, knowledge application, and performance of cross-functional new product development teams. Decision sciences, 34(4), 707-739. https://doi.org/10.1111/j.1540-5414.2003.02350.x

Schneider, M. (2002). A stakeholder model of organizational leadership. Organization Science, 13(2), 209-220.

Singh, S. K. (2008). Role of leadership in knowledge management: a study. Journal of knowledge management, 12(4), 3-15. http://dx.doi.org/10.1108/13673270810884219

Skyrme, D., \& Amidon, D. (1997). The knowledge agenda. Journal of knowledge management, 1(1), 27-37. https://doi.org/10.1108/13673279710800709 
Song, J.H., Kolb, J. A., Hee Lee, U., \& Kyoung Kim, H. (2012). Role of transformational leadership in effective organizational knowledge creation practices: Mediating effects of employees' work engagement. Human Resource Development Quarterly, 23(1), 65-101. https://doi.org/10.1002/hrdq.21120

Spender, J. C. (1996). Making knowledge the basis of a dynamic theory of the firm. Strategic Management Journal, 17(10), 45-62. https://doi.org/10.1002/smj.4250171106

Stone, A.G., Russell, R. F., \& Patterson, K. (2004). Transformational versus servant leadership: A difference in leader focus. Leadership \& Organization Development Journal, 25(4), 349-361. https://doi.org/10.1108/01437730410538671

Theodore, J. (2013). Absence of transformational leadership in Greek enterprises results in the inability of forming learning organizations. The International Business \& Economics Research Journal (Online), 12(6), 701. https://doi.org/10.19030/iber.v12i6.7874

Tung, H. L., \& Chang, Y. H. (2011). Effects of empowering leadership on performance in management team. Journal of Chinese Human Resources Management, 2(1), 43-60. https://doi.org/10.1108/20408001111148720

Valaei, N., Nikhashemi, S. R., \& Javan, N. (2017). Organizational factors and process capabilities in a KM strategy: toward a unified theory. Journal of Management Development, 36(4), 560-580. https://doi.org/10.1108/JMD-04-2016-0057

Valaei, N., Rezaei, S., \& Emami, M. (2016). Impact of exploitative learning strategy on Malaysian SMEs' creativity and innovation capabilities. International Journal of Management and Enterprise Development, 15(4), 328-354. 10.1504/IJMED.2016.079853

Van Dierendonck, D. (2011). Servant leadership: A review and synthesis. Journal of management, 37(4), 1228-1261. https://doi.org/10.1177/0149206310380462

Vandenabeele, W. (2014). Explaining public service motivation: The role of leadership and basic needs satisfaction. Review of Public Personnel Administration, 34(2), 153-173. https://doi.org/10.1177/0734371X14521458

Von Krogh, G., Nonaka, I., \& Rechsteiner, L. (2012). Leadership in organizational knowledge creation: A review and framework. Journal of Management Studies, 49(1), 240-277. https:/doi.org 10.1111/j.1467-6486.2010.00978.x

Wang, A. C., \& Cheng, B. S. (2010). When does benevolent leadership lead to creativity? The moderating role of creative role identity and job autonomy. Journal of organizational behavior, 31(1), 106-121. https://doi.org/10.1002/job.634

Watt, W. M. (2009). Facilitative social change leadership theory: 10 recommendations toward effective leadership. Journal of Leadership Education, 8 (2)-Fall 2009, 50-71.

Wee, J.C.N., \& Chua, A.Y.K. (2013). The peculiarities of knowledge management processes in SMEs: the case of Singapore. Journal of Knowledge Management, 17(6), 958-972. 
http://dx.doi.org/10.1108/JKM-04-2013-0163

Wei, C. C., Choy, C. S., \& Chew, G. G. (2011). The KM processes in Malaysian SMEs: an empirical validation. Knowledge Management Research \& Practice, 9(2), 185-196. https://doi.org/10.1057/kmrp.2011.8

Williams, P. (2012). The role of leadership in learning and knowledge for integration. Journal of Integrated care, 20(3), 164-174. http://dx.doi.org/10.1108/14769011211237500

Wu, I. L., \& Chen, J. L. (2014). Knowledge management driven firm performance: The roles of business process capabilities and organizational learning. Journal of Knowledge Management, 18(6), 1141-1164. http://dx.doi.org/10.1108/JKM-05-2014-0192

Xiao, Y., Zhang, X., \& de Pablos, P. O. (2017). How does individuals' exchange orientation moderate the relationship between transformational leadership and knowledge sharing?. Journal of Knowledge Management, 21(6), 1622-1639. https://doi.org/10.1108/JKM-03-2017-0120

Xue, Y., Bradley, J., \& Liang, H. (2011). Team climate, empowering leadership, and knowledge sharing. Journal of knowledge management, 15(2), 299-312. https://doi.org/10.1108/13673271111119709

Yang, L. R., Huang, C. F., \& Hsu, T. J. (2014). Knowledge leadership to improve project and organizational performance. International Journal of Project Management, 32(1), 40-53. http://dx.doi.org/10.1016/j.ijproman.2013.01.011

Yin, J., Ma, Z., Yu, H., Jia, M., \& Liao, G. (2019). Transformational leadership and employee knowledge sharing: explore the mediating roles of psychological safety and team efficacy. Journal of Knowledge Management. https://doi.org/10.1108/JKM-12-2018-0776

\section{Copyright}

Copyright for this article is retained by the author(s), with first publication rights granted to the journal.

This is an open-access article distributed under the terms and conditions of the Creative Commons Attribution license (http://creativecommons.org/licenses/by/4.0/). 